\title{
Ethical Orientation and Awareness of Tourism Students
}

Dr Simon Hudson

Associate Professor

Haskayne School of Management

University of Calgary

2500 University Drive NW

Alberta T2N 1N4

Tel: (403) 2208378

Fax: (403) 2820095

simon.hudson@haskayne.ucalgary.ca

*Corresponding author
Dr Graham Miller*

Lecturer in Management

School of Management

University of Surrey

Guildford

Surrey GU2 7XH

Tel: 01483683095

Fax: 01483686301

G.Miller@ surrey.ac.uk

To be reviewed as part of the Teaching Business Ethics section. 


\begin{abstract}
The tourism industry is one of the largest industries in the world, and despite recent events that have made its operating environment more complex, the industry continues to grow (Theobald, 2005). Commensurate to the size of the industry is a growth in the number of students pursuing degree courses in tourism around the world. Despite an increasingly sophisticated literature, the relative recency of the industry and its study has meant little attention has been paid in the ethics literature to the dilemmas facing tourism managers and its students. Based on interviews with senior members of the tourism industry six scenarios are developed with pertinence to the challenges faced by industry practitioners today. This paper then applies the Multidimensional Ethics Scale (Reidenbach and Robin, 1990) to tourism students at three prominent universities in the UK, Canada and Australia. In total, 438 responses are achieved. The results have importance for the instruction of tourism students for the future, but also in informing decisions about the tools tourism destinations can effectively employ to control the future direction of the industry.
\end{abstract}

Key words: Tourism, Students, Multi-Dimensional Ethics Scale 


\section{Ethical Orientation and Awareness of Tourism Students}

\section{Introduction}

Much research has been conducted on the ethical awareness and orientation displayed by students studying a range of subject disciplines (Freedman and Bartholemew, 1990; Small, 1992; Okleshen and Hoyt, 1996; Kaynama, King and Smith, 1996; Smith and Oakley, 1997; Cohen, Pant and Sharp, 2001; Stevens, 2001; Kracher, Chatterjee and Lundquist, 2002). Such research has enabled discussion on the necessary future levels of ethical training (Singh, 1989), the way such training should be delivered (Woods and Berger, 1989), the implications for organisational recruitment and selection (Stevens, 2001), the importance of organisational socialisation, and the value of tools, such as codes of ethics, as a way to ensure consistent standards of professionalism (Cleek and Leonard, 1998).

However, while some studies have examined the ethical orientation of hospitality students (Pizam and Lewis, 1979; Whitney, 1989; Freedman and Bartholomew, 1990; Stevens, 2001), no research has been conducted to date on either the ethical perspectives, or the decision making approaches of tourism students. This paper aims to address this shortcoming by measuring both ethical awareness and orientation of a sample of tourism students in three different countries through the application of the Multidimensional Ethics Scale (MES). The structure of the paper is as follows. Initially, the links between tourism, ethics and corporate responsibility are explored. The paper then presents a 
framework for ethical decision making - a framework that can be tested using the MES scale. Previous theory suggests that there are a number of possible influences on ethical decision making of students: nationality or culture, the type of ethical dilemma faced, prior ethical education, and gender. These are discussed in turn, and a general hypothesis is developed from this theory. The paper then presents an empirical study that examines the ethical awareness and orientation of tourism students in three major educational institutions in the UK, Canada, and Australia.

\section{Ethics and tourism}

The substantial growth of tourism activity clearly marks tourism as one of the most remarkable economic and social phenomena of the past century. The number of international arrivals shows an evolution from a mere 25 million international arrivals in 1950 to over 700 million in 2002, corresponding to an average annual growth rate of 6.6 percent (World Tourism Organization, 2005). In addition to the numerical growth of tourism, there has been an increasing geographic spread of tourism to encompass almost all the reaches of the globe. Simultaneously, there has been a diversification of the tourism product from the traditional sun, sea and sand offering to a product that can be potentially more intrusive, or more beneficial for those living in the tourism destination. Tourism's expansion has meant the industry now represents the leading source of foreign exchange in at least $38 \%$ of countries, and ranks in the top five industries for exports in $83 \%$ of countries (WTO, 2005). 
However, in addition to the oft-cited economic indicators displaying the dominance of the tourism industry, there has been a commensurate and almost equally well-publicised rise and recognition of the potentially negative impacts of the burgeoning tourism industry (Archer, Cooper and Ruhanen, 2005). Researchers have been critical of the pernicious social and environmental impacts the industry can have from reinforcing western domination over developing countries through the 'host/guest' relationship (Smith and Brent, 2001) to the visual scars on the landscape caused by ski resorts or golf courses (Hudson, 2000). This has led to calls for the industry to exercise greater responsibility and "professionalism" (Sheldon, 1989) in order to protect the "golden goose" (Manning and Dougherty, 1995) and mirrors the arguments for greater corporate and social responsibility in other industries (Webley, 1999; Rondinelli and Berry, 2000; Huberman-Arnold and Arnold, 2001; Miller, 2001).

Corporate Social Responsibility (CSR) is a specific application of the notion of environmental and social auditing to business practice. The technique is strongly promoted by Fair Trade in Tourism (2000) which suggests that the technique of CSR emerged in the late 1990s out of NGO efforts to create a more equitable international trade system. According to Mowforth and Munt (2003) the tourism industry is well behind other industries in terms of CSR, and the absence of ethical leadership in the tourism industry has been 'astounding'(p.168). However, in the last few decades, responsible tourism has emerged as a significant trend in the western world, as wider consumer market trends towards lifestyle marketing and ethical consumption have spread to tourism (Goodwin and Francis, 2003). Tourism organizations are beginning to realize 
that promoting their ethical stance can be good business as it potentially enhances a company's profits, management effectiveness, public image and employee relations (Fleckenstein and Huebsch, 1999; Hudson and Miller, 2005). Yet, although more attention is now being paid to ethics in tourism (Kalisch, 2002; Holden, 2003) there is a very weak foundation of research into tourism ethics studies to date (Fennell, 1999). The consequence is that the arguments presented for and against CSR in tourism are often simplistic and largely without any practical evidence.

\section{Ethical Decision Making}

The two approaches to ethical decision-making which have received most attention in the literature are those reliant on the theories of deontology and teleology (McDonald and Beck-Dudley, 1994). A deontological approach enjoys a rich historical legacy, dating back to philosophers such as Socrates, and more recently to the work of Kant.

Deontology is concerned with the idea of universal truths and principles, which should be adhered to regardless of the circumstances. Kant's categorical imperative states that a person faced with a problem should be able to respond consistently and in conformity with their moral principles and also feel comfortable with the decision being made in full view of others. A teleological view can be understood as "consequentialism" (Kaynama et al., 1996) following from the philosophical work of Jeremy Bentham and John Stuart Mill on utilitarianism. Thus, ethical decisions are made in view of expected outcomes, which eliminate the universality of decisions and subordinates principles to context. 
A common expression for the two approaches would be that deontology places the means as more important than the end, while for teleology it is the end that justifies the means. Understanding these theories helps to successfully employ the various "tools" that exist to control the tourism industry, ranging from market-based instruments such as taxes through to more command and control instruments such as legislation. For a deontologist, breaking the law would contravene their view of ethics and so the legislation would be abided by almost regardless of the value of the legislation. Yet, a teleologist would consider the consequences of not abiding by the law and would weigh this against the benefits of breaking the law. If tourism students seem to adopt a teleological approach to ethical dilemmas, then legislation can only expect to be effective if accompanied by stringent penalties that make the outlawed behaviour not worthwhile, and hence the need to understand how decisions are made.

Malloy \& Fennell (1998), Cleek \& Leonard (1998) and Stevens (2001) all point to the increasing prevalence of codes of ethics employed by the tourism industry as a tool to provide guidance to employees when making decisions. An important contribution in this area has been made by the World Tourism Organization, who in 1999 approved the Global Code of Ethics for Tourism that consolidated and reinforced previous recommendations and declarations on sustainable tourism. The Code aims to preserve the world's natural resources and cultural heritage from disruptive tourist activities and to ensure a fair and equitable sharing of benefits that arise out of tourism with the residents of tourism destinations. Yet the code is not supported by an understanding of how 
industry practitioners make their decisions. Indeed, the lack of awareness within the industry of the code would indicate the code is not a particularly effective tool.

\section{Influences on Ethical Decision Making}

Previous theory suggests that there are a number of influences on ethical decision making of students, including nationality, the type of ethical dilemma, prior ethical education, and gender. Prior research in cross-cultural or cross-national ethical values of students has been quite contradictory. For example, Lysonski and Gaidis (1991) found that business students' ethical orientations were similar in the USA, Denmark and New Zealand. However, Okleshen and Hoyt (1996) found that US students were less tolerant than New Zealand students of situations involving the ethical constructs of fraud, coercion and self-interest. Whipple and Swords (1992) suggest that the field of business ethics has not attracted the degree of academic interest in the UK as it has in the US, and that more business ethics courses are needed in Britain to counter the difference in ethical judgements found.

Ethical decision making is also likely to be influenced by the type of ethical dilemma faced. Jones (1991) showed ethical issues can be classified according to their intensity, with respondents more likely to respond according to ethical principles if the issue is deemed as important. Applied ethics has evolved for functions and aspects such as business ethics, marketing ethics, and accounting ethics, but discussion of sustainable tourism ethics and the moral appropriateness of sustainable tourism in various contexts is 
somewhat muted by comparison (Fennell, 1999). In western societies over the last few decades, an increased recognition that the world's resources are limited, has led to the strengthening of an environmental ethic, whereby the natural environment is recognised to have an intrinsic value which outweighs its value as a leisure asset (Holden, 2003). Yet, despite understanding the concept of the "triple bottom line", attention to the negative economic and socio-cultural impacts of tourism is less evident (Jamal, 2004). Indeed, a recent review of tourism journals shows a heavy bias in favour of papers that focus on the environmental issues arising from the industry (Hughes, 2005), reflecting the acknowledged predisposition NGOs have previously held towards the environment (Scheyvens, 2002). Through exposure to these debates students are potentially more likely to be sensitive to environmental issues.

The level of ethical education is likely to have an influence on ethical decision making (Whitney, 1989). The last decade has seen an increase in the demands for ethical training amongst tourism students (Tribe, 2002; Jamal, 2004). However, there is little evidence that tourism students are receiving ethical education (Cohen, et al. 2001; Whitney, 1989), and no research has looked at the relationship between this training and ethical decision making. Singh's (1989) survey of Canadian management schools shows that nearly half of all those Universities surveyed did not offer a formal course in business ethics to their students. Enghagen (1991) found a higher proportion of courses were offered in the US for hospitality education, although the majority of ethics courses offered were electives. Studies which have attempted to measure the impact of teaching ethics to students have shown improved, but short-lived improvements in the ethical values and reasoning skills 
of students (Fulmer and Cargile, 1987; Weber, 1990). Harris (1991) found that business majors profess a teleogical (Egoist and Utilitarian) approach, whereas non-business majors prefer a deontological (Golden Rule and Kant's Imperative) approach. Okleshen and Hoyt (1996) concluded from their study that educational experience in an ethics course produces homogeneity and is beneficial towards obtaining cross cultural understanding and congruence in ethical values.

Finally, studies of ethics and gender have found females to be less tolerant than males of situations involving ethical dilemmas (Ferrell and Skinner, 1988; Beltrami et al., 1984; Peterson, Beltramini and Kozmetsky, 1991; Ruegger and King, 1992; Cohen et al., 2001). For example, Whipple and Wolf (1991) found that female students are more critical than their male classmates of questionable business practices. Others (Gilligan, 1982;

Freedman and Bartholomew, 1990) have found student females to have higher moral values than males. Galbraith and Stephenson (1993) demonstrated that female business students prefer a Utilitarian decision rule while male business students prefer an Egoist approach to evaluating ethical dilemmas.

\section{Objectives}

As one of the world's truly global industries, working with a diversity of cultures, moral and ethical values, future business practitioners face the challenge of global ethics (Okleshen and Hoyt, 1996). In order to contribute to the development of understanding of global ethics, this study is responding to calls for the need to document existing ethical 
perspectives of individuals from around the world and to identify the determinants of ethical orientations (Kirande, Rao and Singhapakdi, 2002). From the body of theory presented above, it can be hypothesised that ethical decision making will be influence by nationality, type of ethical dilemma, prior ethical education, and gender. This hypothesis was tested by examining the ethical decision making of students in the UK, Australia and Canada.

\section{Method}

Using case studies or ethical scenarios has been advocated as the most useful way of examining ethical issues and teaching ethical concepts (Stevens, 2001; Vallen and Casado, 2000; Kaynama et al., 1996; Okleshen and Hoyt, 1996). Therefore, five face to face interviews were conducted with human resource directors of the major tour operators in the UK in order to develop ethical scenarios that could later be used to test students' ethical positioning and decision making processes. These large tour operators provide direction to the industry and their stance on ethical problems can be seen as contributing heavily to the context in which decisions made by the rest of the industry are judged. Developing original scenarios was deemed as important in order to avoid 'off-the-shelf' solutions to ethical problems that are widely available. To analyse this qualitative research, Ritchie and Spencer's (1994) framework for qualitative data analysis was followed. Using this five stage process, the researcher firstly familiarises himself with an overview of the research, and then identifies a 'thematic framework' in which the material can be sifted and sorted. The third stage of the framework applies the framework 
and indexes the material using the framework and then charts the data through the use of headings and sub headings. The final stage maps and interprets data, completing a process designed to enhance the internal validity of research by improving the visibility and accessibility of the research.

Six scenarios were developed based on these interviews (see Appendix A) and reflected the three principal areas of concern within the tourism industry. Hence, in order to test the effect of the scenario on the ethical orientation and awareness, following Fennel and Malloy (1999), scenarios 1 and 5 were based on social dilemmas, scenarios 2 and 4 were based on environmental dilemmas, and 3 and 6 were economic in orientation (Jones, 1991; Shaub and Lawrence, 1996).

The Multidimensional Ethics Scale (MES) (Reidenbach and Robin, 1988, 1990; Flory et al., 1992; Cohen et al., 2001) was used to measure the ethical orientation and awareness of the students evaluating these scenarios. The MES has been developed to be used in business contexts and permits insights into the cognitive ethical reasoning process, offering the advantages that specific modes of moral reasoning can be identified. The measures of ethical awareness capture the extent to which respondents feel that a particular action is unethical according to the ethical theories of justice (the equitable distribution of reward and punishment), relativism (there are no universal standards of moral value only cultural norms), and deontology and utilitarianism as explained earlier. These theories have been identified in previous reviews of the moral philosophy literature and although the scale has its critics (Hyman, 1996), it was chosen for use in this study 
because it has been used successfully in many empirical studies, and in particular for its use in the only comparable study conducted to date, examining ethical decision making amongst tour operators (Fennell and Malloy, 1999).

The MES scale used in this study (see Appendix A) is a semantic differential scale consisting of 10 items representing the four dimensions of ethical behaviour referred to above: justice (the idea of fairness to all), deontology (the extent to which an action is consistent with an individual's duties or unwritten obligations), utilitarianism (the extent to which an action leads to the greatest good for the greatest number of people), and relativism (the extent to which an action is considered acceptable in a culture). Respondents were given the six ethical scenarios, and asked to respond in terms of the ten item scale. The polarity of scales was randomized to minimize response effect bias.

The MES scale also contains items that measure ethical intention and overall orientation. Ethical intention was measured using two items. One was in the first person (I would/would not undertake the same action), and the other, to mitigate social desirability bias (Cohen et al., 1998), in the third person (my peers would/would not undertake the same action). One final item on the scale measured the overall level of ethical orientation (the action is ethical/unethical) capturing the weight respondents placed on each of the criteria in their evaluation of the overall morality of an action. In addition to the MES scale, students were asked to indicate their gender, and whether or not they had ever taken a module in ethics. 
The questionnaires were distributed to tourism students in Canada, Australia and the UK in undergraduate tourism programs at three different institutions. Samples were drawn from the student population since they were the focus of this study, and they also meet the requirements of matched samples. The matched samples technique is a method advocated by cross-cultural research methodologists where the samples of cultural groups to be compared are made as similar as possible in their demographic characteristics (Vijver and Leung, 1997). The distribution was achieved via a contact faculty person at each university who distributed them in class. The three samples consisted of all tourism student undergraduates at each institution, giving a sample population of 443. Students were given the option of not participating, and the same instructions were given to each group as to how the instrument was to be completed. Although all students agreed to participate, there were five unusable surveys, resulting in a total of 438 usable responses. Smith and Oakley (1997) argue that social desirability response bias can be high in research topics such as ethics, while Kracher, Chatterjee and Lundquist (2002) believe any research with students in a university setting must confront the risk of respondents seeking the 'right' answer. By stressing the voluntary nature of the survey and conducting the survey at the end of a class the limitations of using University students in research have been recognized. However, the risk of a biased answer needs to be weighed against the value of receiving answers with all its implications for education and understanding the future decision-making of professionals in the industry. 


\section{Results}

Of the 438 responses, 187 were from the UK, 135 from Australia and 116 from Canada (see Table 1). The gender split was $72 \%$ females and $28 \%$ male, typical for students of tourism. Of the total sample, $23 \%$ had received some form of ethical training in the past (defined as having taken a module in ethics), higher than found in previous studies of students (Okleshen and Hoyt, 1996). Canadian students were more likely to have taken an ethics course (41\%) than Australians (24\%) or students form the UK (12\%). A test of the reliability of the questions in each ethical scenario confirmed the dimension structure referred to above. Cronbach alpha scores for each of the four dimensions across the six scenarios met or exceeded the score of 0.70 recommended by Nunnally (1967) and Robinson et al. (1991).

\section{**Table 1 to be inserted here**}

With ' 1 ' representing the positive form of the scale item (e.g. fair) and ' 7 ' the negative form of the item (e.g. unfair), mean scores were calculated for each dilemma by ethical dimension and country (see Table 2). The mean scores show that for Justice, Relativism and Utilitarianism all students deemed the actions taken in the environmental scenarios to be more unethical than for the economic or social scenarios. However, the construct Deontology follows a different pattern with the social scenarios being scored most negatively. These results suggest that ethical decision making approach will be influenced by the type of ethical dilemma faced, and is evidence of a stronger, more principled environmental ethic amongst the students (Holden, 2003). 


\section{**Table 2 to be inserted here**}

A two way repeated measure ANOVA ( 3 x 3 ) was employed with country of study of respondent (3 groups) as a between subject factor and scenarios (3) as a within subject factor, on the 10 item scale. The results of this test (see Table 3) confirmed that there was a significant country by scenario interaction for Justice $[(F 4,866)=3.911, p=.004]$, Deontology $[(\mathrm{F} 4,866)=4.525, \mathrm{p}=.001]$ and for Utilitarianism $[(\mathrm{F} 4,866)=3.463$, $\mathrm{p}=.008]$, which indicates that scenario effects vary with the country or visa versa. These results are an initial indication that ethical decision making approaches will vary across countries. However, there was no significant country by scenario interaction for Relativism $[(\mathrm{F} 4,866)=1.715, \mathrm{p}=.144]$.

\section{**Table 3 to be inserted here**}

For these significant interactions, further investigation involved the testing of simple effects (see Tables 4 and 5). Results indicated that for the Deontology and Utilitarianism dimensions there was a significant scenario effect for Canada, Australia and UK, and for both dimensions there was a significant country effect for the Economic scenarios ([(F2, $434)=6.97, \mathrm{p}=.001 ;[(\mathrm{F} 2,433)=9.74, \mathrm{p}<.001])$. Post hoc analysis $(\mathrm{SNK})$ showed that UK students are significantly more likely to perceive that the ethical decision taken violated an unspoken promise or an unwritten contract, and significantly more likely to 
perceive that the decision taken produced the greatest benefit to all. This suggests they are more teleological in their decision making than students from Canada and Australia.

\section{**Tables 4 and 5 to be inserted here**}

A two way repeated measure ANOVA ( $2 \times 3)$ was also employed with gender of respondent (2 groups) as a between subject factor and scenarios (3) as a within subject factor, on the 10 item scale. The results of this test showed no significant gender by scenario interaction for Justice, Deontology, Utilitarianism or Relativism. A similar test using ethical training as a between subject factor again showed no significant ethical training by scenario interaction for the four dimensions.

The last two items of the MES scale measure ethical intention and overall orientation. Adjusted mean scores were calculated for these measures, and the results are presented in Table 6. Once again there was a significant difference in the responses between countries, controlling for gender and ethical training, especially for the Economic and Social scenarios. For the Economic scenarios, there was a significant difference in ethical intention. Students from the UK indicated that they and their peers were more likely (than the other two student groups) to undertake the same action. For the Social scenarios, Canadian students were significantly more likely to indicate that their peers would take the same action and significantly more likely to say that the action taken was ethical. Australian students were least satisfied ethically with the action taken. For the Environmental scenarios, there was a significant difference in ethical intention between 
genders. Subsequent analysis revealed that females and their peers were significantly less likely (than males) to undertake the same action. Although previous analysis showed no significant gender by scenario interaction for the four ethical dimensions, this does confirm to some extent that female students are more sensitive to ethical issues than their male counterparts. Whether or not respondents had, previously taken a module in ethics had no effect on ethical intention or overall ethical orientation. Ethical decision making (in this study) is therefore not influenced by the level of prior ethical education.

\section{**Table 6 to be inserted here**}

\section{Discussion}

The results show that significant differences in ethical decision making were limited to the Deontology and Utilitarianism subscales in the Economic scenarios only. For the Economic scenarios, UK students were more likely to perceive that the ethical decision made violated an unspoken promise, and more likely to consider if the decision produced the greatest benefit to all, and hence were more teleological in their ethical decision making. For the economic scenarios, UK students were also more likely to indicate that the decision made was an ethical one.

It has been suggested that a teleological approach might have more application in the tourism industry because managers can be taught to compare outcomes to the various 
stakeholders for each possible decision and select the decision that has the best outcomes Khan and McCleary, 1996; Carroll,1989). Previous research supports such a teleological approach for analyzing ethical dilemmas (Jazray, 2002; Blanchard and Peale, 1988; Hall, 1992) and there is potential in the tourism industry for a teleological approach to ethics to be used as a means by which to educate and learn through an understanding of the consequences of one's actions (Malloy and Fennell, 1998). The danger with this approach is that once an (often) economic benefit disappears to protect or preserve, then so does the basis on which the preservation is justified. A deontological underpinning, although less fashionable provides more protection against the vicissitudes of the market. However, a teleological approach would sit comfortably with ethical instruction being interwoven with other subjects of study and avoid ethics being taught as a separate subject, which could prevent students from thinking in a holistic manner.

The results also show that there was no significant country by scenario interaction for Relativism. This supports the work by Cohen et al. (2001) who found that relativism had little effect on ethical decision making. This has potentially an interesting consequence for the use of examples as a way to instruct students, but also to illustrate future directions for industry. If students show that they are guided by what is fair or unfair, right or wrong, has utility or not, but are not particularly guided by the position of others, then demonstrating what others have done in a similar scenario is not appealing to a form of decision making that students employ. As such, case studies may be useful to demonstrate the range of actions possible, or to encourage students to consider what alternatives are available, but this survey would suggest that students are not likely to be 
guided by examples of what others have done. This finding may be contained to this particular study and it might be that with a sample of people working in the industry then a more relativistic approach is valuable. However, further research could seek to ascertain the usefulness of best practice type examples in providing ethical instruction to students.

The fact that prior ethical education had no effect on the students' responses in any of the analysis, contradicts previous findings (Okleshen and Hoyt, 1996). Although 41\% of Canadian students had taken an ethics module (compared to 24\% in Australia and 12\% in the UK), it does not appear that they are any more sensitive to ethical issues. It may be a concern to British tourism educators that only $12 \%$ of students had taken an ethics course. Previous studies have found UK firms to be lagging behind their US counterparts in response to ethical concerns (Schlegelmilch, 1989), and there have been calls for more business ethics courses at British Universities (Whipple and Swords, 1992). However, it should be acknowledged that even though the majority of students in this study indicated that they had not taken an ethics module during the course of their studies, it does not mean they have not received any ethical training. Indeed, the ethical training students have received may have been embedded within the study of other subjects and so not discerned as separate ethical training. This demonstrates the difficulty of identifying the effect of ethical training and certainly needs further investigation.

Similar to many prior studies referred to earlier in the paper, the results indicated that female students are more sensitive to ethical issues than males in terms of their ethical intention - particularly for environmental issues. These findings suggest that as more and 
more women complete their education and enter the business world, ethical decision making in organizations may change (Whipple and Swords, 1992). Also, educators who are developing and teaching business ethics and social responsibility course should pay attention to gender differentiated development needs. Respondents as a whole (and not just female students) were least satisfied with the decision taken with the environmental scenarios. This supports the contention made previously, that students are more exposed to ethical scenarios related to the environment (Hughes, 2005). There is a need therefore, for the tourism curriculum to integrate more social and economic ethical dilemmas.

In terms of informing decisions on the use of tools to direct the tourism industry, the dismissal of Relativism would suggest that tools that rely on pressure to conform to what other members of the industry are doing would be ineffective. Malloy and Fennell (1998), Cleek and Leonard (1998) and Stevens (2001) all point to the increasing prevalence of codes of ethics employed by organisations as a way of promoting more ethically consistent decisions by their employees. While Malloy and Fennell (1998) declare the majority of codes to be deontological in their language, no previous study has sought to assess ethically how decisions are made by those that are subject to the codes. Hence, voluntary efforts such as 'compacts' or attempts to 'name and shame' may not be useful. The evident use made of Deontology, Justice and Utilitarianism demonstrates that codes of ethics may be valuable, but more research is needed to interrogate these relationships further. Further research showing whether tourism managers applied a more teleological approach to decisions would reveal deontological codes of ethics to be little 
more than an exercise in promoting external goodwill, while the opposite finding strengthens the case for codes of ethics (Rondinelli and Berry, 2000).

Although there were significant differences across the three institutions, there were many commonalities in ethical decision making in this study. This may reflect the similar cultures and the common educational systems of the three countries chosen, but it bodes well for the application of a consistent approach to tourism management throughout the world, as well as the introduction of common tools and educational approaches. A natural sequitur of research into the level of ethics displayed by students is the ethical orientations of those in organisations. Stevens (2001) believes ethics for the hospitality industry to be crucial because of the situations in which employees are regularly placed. This coupled with the high turnover rate of employees makes the industry susceptible to dishonesty and the acquisition of a poor reputation. Rondinelli and Berry (2000) demonstrate the focus many large enterprises pay to internal issues in a bid to promote more sustainable practices (whether for intrinsic or extrinsic reasons), but often fail to draw sufficient attention through external practices (such as community projects, sponsored clean-ups etc) to the behaviour of the organisation. By contrast, Wight (1994) illustrates the existence of companies who engage in more external practices in a bid to conceal a lack of internal actions and so engage in "greenwash". In addition to the harm done to the reputation of the industry, such practices serve to create an illusion of what working for a particular organisation, or in a particular industry would be like. Research into the ethical approaches and positions of tourism managers and employees would assists in ensuring more appropriate, or at least better prepared, students join tourism 
organisations. As such, the ethical scenarios developed through interviews with senior members of the industry makes a strong contribution to future research and as an aid to teaching in this area.

\section{Conclusion}

The tourism literature makes a continual call for more decisions to be made that acknowledge the full impacts of the industry and yet little research has been conducted that attempts to establish the ethical framework the managers of the future will employ to approach these decisions. This research has drawn on the work of other subject disciplines and applied an established research methodology to tourism students in three different countries. Such research has enabled more informed discussions about what is required from ethical instruction in the future. It should be noted that the intention of this research was not to determine what is ethical or unethical. Rather, it was to assess how the characteristics of issues influence ethical beliefs, how individuals think and devise what is ethical and unethical and how different variables influence ethical perceptions (Trevino, 1986). Once greater knowledge exists about how students and businesses are making decisions, then discussions of which tools are appropriate to enable or constrain those decisions become more apposite. 


\section{Appendix A: MES and Ethical Scenarios}

\section{Scenario Number 1}

A major tour operator doesn't charge disabled customers extra money to travel despite the fact that the tour operator itself is being charged more by the airline and the hotels for the difficulty of transporting wheelchairs and the extra care and time necessary with disabled customers. This policy results in the tour operator being increasingly popular with disabled customers, but this is costing the tour operator money.

\section{Action:}

The tour operator decides to offer the same policy as all the other major tour operators and pass on the charges levied by the airlines and hotels, and so reduce the number of its disabled customers.

Your response to the action is that it is...

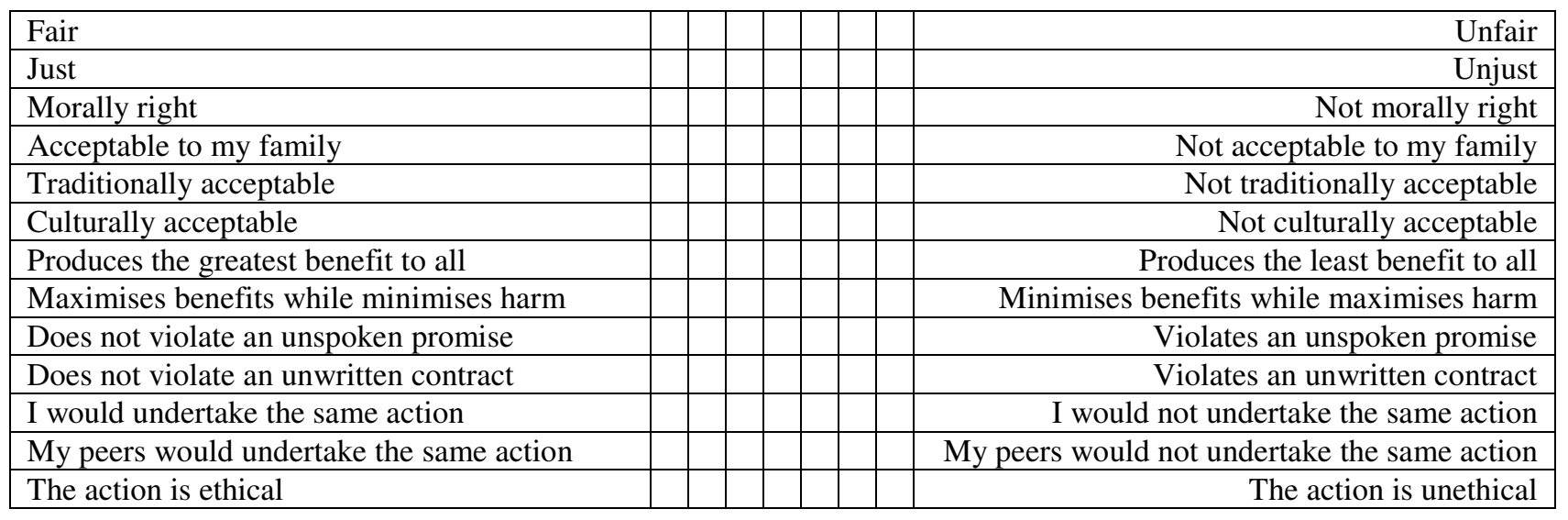

\section{Scenario Number 2}

A major international tourism developer has plans to build a significant development in an undeveloped area of a lesser developed country. The resort will bring much needed employment, investment and, it is argued, a reason for the young of the town not to migrate to the big cities. The centrepiece of the new resort is planned to be a 72-hole golf course. The local residents are worried that to provide enough water for the golf course and electricity for the resort will mean local supplies are negatively affected. Fishermen are worried that the run off from the pesticides used on the golf course will have severe effects on the health of their fish stocks.

\section{Action:}

The development goes ahead as planned and does negatively affect the local electricity and water supplies while harming fish stocks.

\section{Scenario Number 3}

The downturn in the tourism industry as a result of the increase in global terrorism has meant a large tour operator has to make redundancies for the first time in its history. There are several members of staff with very high records of absenteeism due to personal illness and thus very low levels of productivity. Some of these members of staff have been with the tour operator for a very long time, and two have been with the company since it first began in business over 25 years ago. Prior to the recent terrorism the company was expanding and had just recruited 20 university graduates who are currently spending 6 months shadowing managers in the different areas of the business before they settle into their permanent positions. The company realises that to make the new recruits redundant will be much cheaper than to make the long time employees redundant even though the company expects the new graduates will be more productive in the long term.

\section{Action:}

The Company makes 20 new graduates redundant and blames the economic downturn caused by terrorism.

\section{Scenario Number 4}

A large resort produces high amounts of sewage, which is piped into the sea surrounding the resort. There are no laws to prevent the resort from disposing of its sewage in this manner, but it is believed that this 
sewage is responsible for the deterioration in the quality of the coral, which has led to complaints from local SCUBA diving operators. The resort does not operate any diving itself as its guests are largely retired couples who prefer to use the resort's many swimming pools. The resort argues that to dispose of its sewage in a way that protected the coral would involve considerable cost.

\section{Action:}

The resort continues to dispose of its sewage directly into the sea and this continues to affect the coral.

\section{Scenario Number 5}

A small, remote community feels very strongly about preserving the Sabbath and has refused to allow flights on Sundays to land or depart from its airport. However, the natural beauty of the island and its abundance of bird life has made it increasingly popular with tourists and provided the local economy with a much needed source of income. In order to take advantage of a strong demand from those wanting to take weekend breaks there is a proposal from the only airline serving the island to begin flights on Sundays during the main tourist season.

\section{Action:}

The airline begins a limited number of Sunday flights.

\section{Scenario Number 6}

Two tour reps in a destination are responsible for selling excursions to the package tourists once they arrive. The excursions represent an important part of the income for the tour operator who relies on highpressure sales tactics by the reps to sell the excursions. The two tour reps feel that although they work hard and work for very long hours they are not paid enough to live properly. The reps decide that as most customers pay cash, they could keep the money paid by some people going on the excursion, let those people onto the coach as normal but not tell the company.

\section{Action:}

The tour reps decide to keep the cash from two customers per excursion and benefit $£ 25$ each per week from doing so. 


\section{References}

Archer, B., C. Cooper, and L. Ruhanen.: 2005, 'The Positive and Negative Impacts of

Tourism', in W.F. Theobald (ed.), Global Tourism ( $3^{\text {rd }}$ edition), (Butterworth-

Heinemann/Elsevier, New York), pp. 79-102.

Arlow, P.: 1991, 'Personal Characteristics in College Students' Evaluations of Business

Ethics and Corporate Social Responsibility', Journal of Business Ethics 10, 63-69.

Beltrami, R.F., R.A. Peterson and G. Kozmersky.: 1984, 'Concerns of College Students

Regarding Business Ethics', Journal of Business Ethics 3, 195-200.

Blanchard, K. and N.V. Peale.: 1988, The Power of Ethical Management (William Morrow and Co. Inc., New York).

Carroll, A.B.: 1989, Business and Society: Ethics and Stakeholder Management (Cincinnati, Ohio, South-Western Publishing Co.).

Cleek M.A. and S.L. Leonard.: 1998, 'Can Corporate Codes of Ethics Influence Behaviour?', Journal of Business Ethics 17(6), 619-630.

Cohen J.R., L.W. Pant, and D.J. Sharp.: 1998, 'The Effect of Gender and Academic Discipline Diversity on the Ethical Evaluations, Ethical Intentions and Ethical 
Orientation of Potential Public Accounting Recruits', Accounting Horizons 12(3), 250270.

Cohen J.R., L.W. Pant, and D.J. Sharp.: 2001, 'An Examination of Differences in Ethical Decision-Making Between Canadian Business Students and Accounting Professionals', Journal of Business Ethics 30(4), 319-336

Enghagen, L.K.: 1990, 'Ethics in Hospitality/Tourism Education: A Survey', Hospitality Research Journal 14 (2), 113-118.

Fair Trade in Tourism Network.: 2002, Corporate Futures: Social Responsibility in the Tourism Industry (London, Fair Trade in Tourism Network).

Fennell, D.: 1999, Ecotourism: An Introduction (Routledge, London).

Fennel, D.A. and D.C. Malloy.: 1999, 'Measuring the Ethical Nature of Tourism Operators', Annals of Tourism Research 26(4), 928-944.

Ferrell, O.C. and S.J. Skinner.: 1988, 'Ethical Behaviour and Bureaucratic Structure in Marketing Research Organizations', Journal of Marketing Research 25, 103-109.

Fleckenstein, M.P. and P. Huebsch.” 1999, 'Ethics in Tourism - Reality or Hallucination', Journal of Business Ethics 19(1), 137-143. 
Flory, S., T. Philips, R. Reidenbach, and D.P. Robin.: 1992, ‘A Multidimensional Analysis of Selected Issues in Accounting', Accounting Review 67(2), 284-302.

Freedman, A.M. and P.S. Bartholemew.: 1990, 'Age/Experience and Genders as Factors in Ethical Development of Hospitality Managers and Students', Hospitality Research Journal 14(2), 1-10.

Fulmer, W.E. and B.R. Cargile.: 1987, 'Ethical Perceptions of Accounting Students: Does Exposure to a Professional Code of Ethics Help?', Issues in Accounting Education (Fall), 207-219.

Galbraith, S. and H.B. Stephenson.: 1993, 'Decision Rules Used by Male and Female Business Students in Making Ethical Judgments: Another Look', Journal of Business Ethics 12, 227-233.

Gilligan, C.: 1982, In a Different Voice (Harvard University, Cambridge, Mass).

Goodwin, H., and J. Francis.: 2003, 'Ethical and Responsible Tourism: Consumer Trends in the UK', Journal of Vacation Marketing 9(3), 271-282. 
Hall, S.J.: 1992, 'The Emergence of Ethics in Quality', in S.J. Hall (ed.), Ethics in Hospitality Management: A Book of Readings (Educational Institute of the American Hotel and Motel Association, East Lansing, MI).

Harris, J.A.: 1991, 'Ethical Values and Decision Processes of Business and Non-Business Students: A Four Group Study', Journal of Legal Studies Education 9, 216-230.

Holden, A.: 2000, Environment and Tourism (Routledge, London).

Holden, A.: 2003, 'In Need of a New Environmental Ethic for Tourism', Annals of Tourism Research 30(1), 94-108.

Huberman-Arnold D., and K. Arnold.: 2001, ‘Commerce With a Conscience: Corporate Control and Academic Investment', Business Ethics: A European Review 10(4), 294301.

Hudson, S.: 2000 Snow Business: A Study of the International Ski Industry (London, The Continuum International Publishing Group)

Hudson, S., and G. Miller.: 2005 'The Responsible Marketing of Tourism: The Case of Canadian Mountain Holidays', Tourism Management 26(2), 133-142. 
Hughes, M.: 2005 'An Analysis of the Sustainable Tourism Literature’, CAUTHE Conference, Alice Springs, Australia, $1^{\text {st }}-5^{\text {th }}$ February.

Hyman, M.R.: 1996, 'A Critique of the Multidimensional Ethics Scale', Journal of Empirical Generalizations in Marketing Science 1, 1-35.

Jamal, T.B.: 2004 'Virtue Ethics and Sustainable Tourism Pedagogy: Phronesis, Principles and Practice', Journal of Sustainable Tourism 12(6), 530-545.

Jazray, C.: 2002, 'Teaching Ethics in Hospitality Programs', Journal of Hospitality \& Tourism Education 14(3), 57-63.

Jones, T, M.: 1991, 'Ethical Decision-Making by Individuals in Organisations: An Issuecontingent Model', Academy of Management Review, April, 366-395.

Kalisch, A.: 2002, Corporate Futures: Social Responsibility in the Tourism Industry. Consultation on Good Practice (Tourism Concern, London).

Kirande, K., C.P. Rao, and A. Singhapakdi.: 2002, 'Moral Philosophies of Marketing Managers: A Comparison of American, Australian, and Malaysian Cultures', European Journal of Marketing 36(7/8), 768-793. 
Khan, M.M. and K.W. McCleary.: 1996, ‘A Proposed Model for Teaching Ethics in Hospitality', Hospitality \& Tourism Educator 8(4), 7-11.

Kaynama, A., A. King and L.W. Smith.: 1996, 'The Impact of a Shift in Organizational Role on Ethical Perceptions: A comparative study', Journal of Business Ethics 15(5), $581-590$

Kracher B., A. Chatterjee A. and A.R. Lundquist.: 2002, 'Factors Related to the Cognitive Moral Development of Business Students and Business Professionals in India and the United States: Nationality, Education, Sex and Gender', Journal of Business Ethics 35, 255-268.

Lysonski, S. and W. Gaidis.: 1991, 'A Cross Cultural Comparison of the Ethics of Business Students', Journal of Business Ethics 10, 141-150.

Malloy, D. C. and D.A. Fennell.: 1998, 'Codes of Ethics and Tourism: An Exploratory Content Analysis', Tourism Management 19(5), 453-461.

Manning, E.W. and T. Dougherty.: 1995, 'Sustainable Tourism: Preserving the Golden Goose', Cornell Hotel and Restaurant Administration Quarterly April, 29-42.

McDonald, J.E. and C.L. Beck-Dudley.: 1994, ‘Are Deontology and Teleology Mutually Exclusive?', Journal of Business Ethics 13, 615-623. 
Miller, G.: 2001, 'Corporate Responsibility in the UK Tourism Industry', Tourism Management 22(6), 500-512.

Mowforth, M. and I. Munt.: 2003, 'Tourism and Sustainability: Development and New Tourism in the Third World (London, Routledge).

Nunnally, J.C.:1967, Psychometric Methods (McGraw-Hill, New York).

Okleshen, M. and R. Hoyt.: 1996, ‘A Cross Cultural Comparison of Ethical Perspectives and Decision Approaches of Business Students: United States of America Versus New Zealand', Journal of Business Ethics 15, 537-549.

Peterson, R.A., R.F. Beltramini and G. Kozmetsky.: 1991, 'Concerns of College Students Regarding Business Ethics: A Replication', Journal of Business Ethics 10, 733-738.

Pizam, A. and R.C. Lewis.: 1979, 'Work Values of Hospitality Students', Journal of Hospitality Education 3, 5-16. 
Reidenbach, R.E. and D.P. Robin.: 1988, 'Some Initial Steps Towards Improving the Measurement of Ethical Evaluations of Marketing Activities', Journal of Business Ethics 7, 871-879.

Reidenbach, R.E. and D.P. Robin.: 1990, 'Towards the Development of a Multidimensional Scale for Improving Evaluations of Business Ethics', Journal of Business Ethics 9, 639-653.

Ritchie, J. and L. Spencer.: 1994, 'Quality Data Analysis for Applied Policy Research', in A. Bryman and R.G. Burgess (eds.), Analysing Qualitative Data (Routledge, London), pp.173-194.

Robinson, J.P., O.R. Shaver and L.S. Wrightsman.: 1991, Measures of Personality and Social Psychological Attitudes (The Academic Press, San Diego, CA.).

Rondinelli, D.A. and M.A. Berry.: 2000, 'Environmental Citizenship in Multinational Corporations: Social Responsibility and Sustainable Development', European Management Journal 18(1), 70-84.

Ruegger, B. and E.W. King.: 1992, 'A Study of the Effect of Age and Gender Upon Student Business Ethics', Journal of Business Ethics 11, 179-186. 
Scheyvens, R. 2002 Tourism for Development: Empowering Communities (Pearsons, Essex).

Schlegelmilch, B.: 1989, 'The Ethics Gap Between Britain and the United States: A Comparison of the State of Business Ethics in Both Countries', European Management Journal 7(1), 57-64.

Shaub, M. and J.E. Lawrence.: 1996, 'Experience and Professional Skepticism: A Situational Analysis', Behavioural Research in Accounting (Supplement), 124-157.

Sheldon, P.: 1989, 'Professionalism in Tourism and Hospitality', Annals of Tourism Research 16, 492-503.

Singh, J.B.: 1989, 'The Teaching of Ethics in Canadian Schools of Management and Administrative Studies', Journal of Business Ethics 8, 51-56.

Small, M.W.: 1992, 'Attitudes Towards Business Ethics Held by Western Australian Students: A Comparative Study', Journal of Business Ethics 11, 745-752.

Smith, P.L. and E.F. Oakley.: 1997, 'Gender-Related Differences in Ethical and Social Values of Business Students: Implications for Management', Journal of Business Ethics $16(1), 37-45$. 
Smith, V. L. and M. Brent.: 2001, Hosts and Guests Revisited: Tourism Issues of the $21^{\text {st }}$ Century (Cognizant, New York).

Stevens B.: 2001, 'Hospitality Ethics: Responses from Human Resource Directors and Students to Seven Ethical Scenarios', Journal of Business Ethics 30(3), 233-242.

Theobald, W.F.: 2005, ‘The Meaning, Scope, and Measurement of Travel and Tourism’, in W.F. Theobald (ed.), Global Tourism ( $3^{\text {rd }}$ edition), (Butterworth-Heinemann/Elsevier, New York), pp. 5-24.

Trevino, L.K.: 1986, 'Ethical Decision-Making in Organizations: A Person-Situation Interactionist Model', Academy of Management Review 11(3), 601-617.

Tribe, J.: 2002, 'Education for Ethical Tourism', Journal of Sustainable Tourism 10 (4), 309-324.

Vallen, G. and M. Casado.: 2000, 'Ethical Principles for the Hospitality Curriculum', Cornell Hotel and Restaurant Administration Quarterly April, 44-51.

Vijver, F. and K. Leung.: 1997, Methods and Data Analysis for Cross-cultural Research (Sage, Thousand Oaks). 
Weber, J.: 1990, 'Measuring the Impact of Teaching Ethics to Future Managers: A

Review, Assessment, and Recommendation', Journal of Business Ethics 9, 183-190.

Webley, S.: 1999, ‘Sources of Corporate Values’, Long Range Planning 32(2), 173-178.

Whipple, T.W. and D.D. Wolf.: 1991, 'Judgments of Marketing Students About Ethical Issues in Marketing Research: A Comparison to Marketing Practitioners', Journal of Marketing Education 13, 56-63.

Whipple, T. W. and D.F. Swords.: 1992, 'Business Ethics Judgments: A Cross Cultural Comparison', Journal of Business Ethics 11, 671-678.

Whitney, D. L.: 1989, 'The Ethical Orientations of Hotel Managers and Hospitality

Students: Implications for Industry, Education, and Youthful Careers', Hospitality Education and Research Journal 13(3), 187-192.

Wight, P.:1994, 'Environmentally Responsible Marketing of Tourism', in E. Cater, and G. Lowman (eds.), Ecotourism: A Sustainable Option? (John Wiley and Son, New York), pp. 39-55.

Woods, R.H. and F. Berger.: 1989, ‘Teaching Social Responsibility’, Cornell Hospitality Restaurant Administration Quarterly August, 61-63. 
World Tourism Organisation.: 2005, Tourism Highlights (Retrieved May 14, 2005 from http://www.world-tourism.org ) 
Table 1: Description of respondents

\begin{tabular}{|c|c|c|c|c|}
\hline & Canada & U.K. & Australia & Overall \\
\hline $\begin{array}{c}\text { Number of } \\
\text { Respondents }\end{array}$ & $\mathrm{n}=116$ & $\mathrm{n}=187$ & $\mathrm{n}=135$ & $\mathrm{n}=438$ \\
\hline Gender & $\mathrm{M}: \mathrm{n}=35(30 \%)$ & $\mathrm{M}: \mathrm{n}=47(25 \%)$ & $\mathrm{M}: \mathrm{n}=42(31 \%)$ & $\mathrm{M}: \mathrm{n}=124(28 \%)$ \\
$\mathrm{F}: \mathrm{n}=81(70 \%)$ & $\mathrm{F}: \mathrm{n}=140(75 \%)$ & $\mathrm{F}: \mathrm{n}=93(69 \%)$ & $\mathrm{F}: \mathrm{n}=314(72 \%)$ \\
\hline Number with & $\mathrm{n}=47$ & $\mathrm{n}=23$ & $\mathrm{n}=32$ & $\mathrm{n}=102$ \\
ethical training & $41 \%$ & $12 \%$ & $24 \%$ & $23 \%$ \\
\hline
\end{tabular}


Table 2: Mean scores for each dilemma by ethical dimension and country

\begin{tabular}{|c|c|c|c|c|}
\hline Scenario & Justice & Relativism & Deontology & Utilitarianism \\
\hline & CAN UK AUS & CAN UK AUS & CAN UK AUS & CAN UK AUS \\
\hline Economic & $\begin{array}{lll}4.92 & 4.70 & 4.85\end{array}$ & $\begin{array}{lll}4.35 & 4.32 & 4.61\end{array}$ & $3.02 \quad 3.44 \quad 3.15$ & $\begin{array}{lll}4.75 & 4.27 & 4.63\end{array}$ \\
\hline Social & $\begin{array}{lll}3.64 & 3.91 & 3.79\end{array}$ & $\begin{array}{lll}3.95 & 4.27 & 4.25\end{array}$ & $3.95 \quad 3.713 .85$ & $\begin{array}{lll}3.87 & 3.92 & 3.99\end{array}$ \\
\hline Environment & $\begin{array}{lll}5.73 & 5.50 & 5.45\end{array}$ & $\begin{array}{lll}4.67 & 4.76 & 5.02\end{array}$ & $\begin{array}{llll}3.42 & 3.39 & 3.38\end{array}$ & $\begin{array}{lll}5.47 & 5.38 & 5.41\end{array}$ \\
\hline
\end{tabular}


Table 3. Two-way repeated ANOVA table for Country by Scenario Theory

\begin{tabular}{|l|ll|ll|ll|}
\hline \multirow{2}{*}{ Ethical theory } & \multicolumn{2}{|l|}{$\begin{array}{l}\text { Country by scenario } \\
\text { interaction effect }\end{array}$} & \multicolumn{2}{l|}{ Scenario effect } & \multicolumn{2}{l|}{ Country effect } \\
\cline { 2 - 8 } & $\mathbf{F}(\mathbf{4 , 8 6 6 )}$ & $\mathbf{p}-$-value & $\mathbf{F}(\mathbf{2 , 8 6 6 )}$ & p-value & F(2,433) & p-value \\
\hline Justice & 3.911 & $.004^{*}$ & 384.732 & $<.001^{*}$ & .428 & .652 \\
\hline Deontology & 4.525 & $.001^{*}$ & 43.642 & $<.001^{*}$ & .292 & .747 \\
\hline Utilitarianism & 3.463 & $.008^{*}$ & 261.276 & $<.001^{*}$ & 3.760 & $.024^{*}$ \\
\hline Relativism & 1.715 & .144 & 51.193 & $<.001^{*}$ & 6.939 & $.001^{*}$ \\
\hline
\end{tabular}

\section{*significance at $\mathbf{0 . 0 5}$ level}


Table 4. Simple effects testing: Scenario effect on each ethical dimension by country

\begin{tabular}{|c|c|c|c|c|c|c|}
\hline Scenario & \multicolumn{2}{|c|}{ Justice } & \multicolumn{2}{|c|}{ Deontology } & \multicolumn{2}{|c|}{ Utilitarianism } \\
\hline & $F(2,866)$ & p-value & F $(2,868)$ & p-value & $F(2,866)$ & p-value \\
\hline Canada & 146.03 & $<.001 *$ & 24.99 & $<.001 *$ & 81.74 & $<.001 *$ \\
\hline Australia & 109.74 & $<.001 *$ & 17.03 & $<.001 *$ & 75.69 & $<.001 *$ \\
\hline UK & 135.34 & $<.001 *$ & 5.32 & $<.001 *$ & 120.38 & $<.001 *$ \\
\hline
\end{tabular}

\section{*significance at $\mathbf{0 . 0 5}$ level}


Table 5. Simple effects testing: Country effect on each ethical dimension by scenario

\begin{tabular}{|c|c|c|c|c|c|}
\hline Scenario & \multicolumn{2}{|c|}{ Justice } & \multicolumn{2}{|c|}{ Deontology } & Utilitarianism \\
\hline & $F(2,433)$ & p-value & $F(2,434)$ & p-value & F $(2,433)$ p-value \\
\hline Economic & 1.99 & .138 & 6.97 & $.001 *$ & $9.74<.001 *$ \\
\hline Social & 2.67 & .071 & 1.97 & .141 & $0.52 \quad .595$ \\
\hline Environmental & 2.92 & .055 & 0.03 & .975 & 0.28 \\
\hline
\end{tabular}

\section{*significance at $\mathbf{0 . 0 5}$ level}


Table 6. Adjusted mean scores for ethical orientation and intention by country, with gender and ethical training as covariates (on a scale of 1-7)

\begin{tabular}{|l|l|l|l|l|l|l|}
\hline & $\begin{array}{l}\text { Canada } \\
\mathbf{n = 1 1 6}\end{array}$ & $\begin{array}{l}\text { UK } \\
\mathbf{n = 1 8 7}\end{array}$ & $\begin{array}{l}\text { Aus } \\
\mathbf{n = 1 3 5}\end{array}$ & $\begin{array}{l}\text { Country } \\
\text { effect }\end{array}$ & Gender & $\begin{array}{l}\text { Ethical } \\
\text { Training }\end{array}$ \\
\hline Economic Scenarios & & & & & & \\
\hline I would undertake the same action & $\mathbf{5 . 0 6}$ & $\mathbf{4 . 6 2}$ & $\mathbf{5 . 1 8}$ & $\mathbf{p}<.001 *$ & $\mathbf{. 1 2 6}$ & $\mathbf{. 4 0 3}$ \\
\hline My peers would take the same action & $\mathbf{4 . 5 3}$ & $\mathbf{4 . 4 4}$ & $\mathbf{4 . 8 1}$ & $\mathbf{. 0 2 8}$ & $\mathbf{. 3 4 1}$ & $\mathbf{. 5 7 8}$ \\
\hline The action is ethical & $\mathbf{5 . 1 1}$ & $\mathbf{4 . 9 2}$ & $\mathbf{5 . 2 1}$ & $\mathbf{. 0 6 2}$ & $\mathbf{. 7 1 3}$ & $\mathbf{. 4 9 2}$ \\
\hline Social Scenarios & & & & & & \\
\hline I would undertake the same action & $\mathbf{3 . 6 3}$ & $\mathbf{3 . 9 0}$ & $\mathbf{4 . 0 4}$ & $\mathbf{. 0 7 0}$ & $\mathbf{. 4 5 2}$ & $\mathbf{. 9 7 8}$ \\
\hline My peers would take the same action & $\mathbf{3 . 3 2}$ & $\mathbf{3 . 8 7}$ & $\mathbf{3 . 8 8}$ & $\mathbf{p}<.001^{*}$ & $\mathbf{. 5 1 7}$ & $\mathbf{. 5 0 0}$ \\
\hline The action is ethical & $\mathbf{3 . 7 8}$ & $\mathbf{4 . 4 7}$ & $\mathbf{4 . 2 3}$ & $\mathbf{p}<.001^{*}$ & $\mathbf{. 9 3 9}$ & $\mathbf{. 3 3 3}$ \\
\hline Environmental Scenarios & & & & & & \\
\hline I would undertake the same action & $\mathbf{5 . 8 9}$ & $\mathbf{5 . 5 9}$ & $\mathbf{5 . 7 5}$ & $\mathbf{. 0 8 8}$ & $\mathbf{. 0 0 2} *$ & $\mathbf{. 8 0 2}$ \\
\hline My peers would take the same action & $\mathbf{4 . 9 9}$ & $\mathbf{5 . 0 4}$ & $\mathbf{5 . 2 5}$ & $\mathbf{. 2 1 7}$ & $\mathbf{. 0 0 9} *$ & $\mathbf{. 3 9 8}$ \\
\hline The action is ethical & $\mathbf{5 . 9 6}$ & $\mathbf{5 . 7 7}$ & $\mathbf{5 . 8 2}$ & $\mathbf{. 3 5 0}$ & $\mathbf{. 6 0 3}$ & $\mathbf{. 4 0 4}$ \\
\hline & & & & & & \\
\hline
\end{tabular}

\section{*significance at 0.05 level}

